\title{
Curriculum evaluation of French learning in senior high school
}

\author{
${ }^{* 1}$ Irma Nur Afidah; ${ }^{2}$ Amat Jaedun \\ ${ }^{1}$ Graduate School, Universitas Negeri Yogyakarta \\ Jl. Colombo No. 1, Karangmalang, Depok, Sleman, Yogyakarta 55281, Indonesia \\ ${ }^{2}$ Faculty of Engineering, Universitas Negeri Yogyakarta \\ Jl. Colombo No. 1, Karangmalang, Depok, Sleman, Yogyakarta 55281, Indonesia \\ *Corresponding Author. E-mail: irmanurafidah15.2017@student.uny.ac.id
}

Submitted: 5 November 2019 | Revised: 20 December 2019 | Accepted: 24 February 2020

\begin{abstract}
The research aims to describe the implementation of French language learning in high schools of Sleman Regency viewed from the components of planning, implementation, and results. This evaluation research uses a quantitative descriptive approach with a countenance model from Stake. Respondents in this research were teachers and students at three senior high schools. Data collection techniques used in this study include research lesson plans, questionnaires, and documentation. The results of this research indicate that: (1) in the planning component, the quality of lesson plan preparation is very good and needs to be maintained because in the lesson plan review, the results obtained are $88.9 \%$ and the teacher questionnaire results of 26.6 are included in the excellent category; (2) in the implementation component, it has good results with the acquisition of a total score of 77 and a student questionnaire of 66.19; (3) in the component of the results, good results are obtained with an average value of students that is 86.38 and the results of the teacher questionnaire of 65.7 which is above 61 so that it falls into the good category. Student scores are obtained from the results of the middle semester assessment and teacher questionnaire.
\end{abstract}

Keywords: curriculum evaluation, countenance model, French learning

How to cite: Af'idah, I., \& Jaedun, A. (2020). Curriculum evaluation of French learning in senior high school. REiD (Research and Evaluation in Education), 6(1), 10-19. doi:https://doi.org/10.21831/reid.v6i1.28006.

\section{Introduction}

Evaluation in education is very broad since it includes various activities such as student assessment, measurement, testing, program evaluation, school personnel evaluation, school accreditation, and curriculum evaluation (Anh, 2018, pp. 140-141). Evaluation has an important role in every research as well as in academic studies. Moreover, important points in the evaluation must meet the values that underlie the curriculum, pedagogy, and results which are the main focus in educational values (Lai \& Kushner, 2013, p. 24). Evaluation involves conducting research activities by an evaluator to provide information on the subject and object of the evaluation (Johnson \& Christensen, 2000, p. 7; McCormick \& James, 2019, p. 13). Evaluation is present when an educational process is carried out by the school and when the teacher takes part in the task of parents in educating (Hasan, 2009, p. 3). Evaluation conducted by the teacher to students is done to find out how the abilities and knowledge of students in understanding the subject matter that has been studied to assess, correct, and improve a program systematically (Tyler, 2013, p. 10). From the definition of evaluation, it is found the definition in curriculum evaluation, which is, scientific research conducted systematically to improve the curriculum applied in education. 
The curriculum is an activity and learning experience, as well as everything that affects the personal formation of students, both at school and also outside of school for the school's responsibility to achieve educational goals (Arifin, 2011, p. 5). The curriculum as a learning plan is a facility in an educational program that serves as a guide and tool in teaching students. The curriculum aims to achieve a field in a subject that adheres to the categorization in education (Hamalik, 2008). These objectives make the curriculum as a benchmark and foundation in implementing learning in schools.

The curriculum becomes the operationalization of the concept of a curriculum that is still written in the actual form of learning, where learning in the classroom becomes a place to implement and test the curriculum to ensure the implementation of the curriculum in schools goes well (Majid \& Rochman, 2014 , p. 23). One of the problems of education in Indonesia in the education system is the frequent change of curriculum. Curriculum development as a curriculum based on character and competence to produce a generation that is competent, innovative, productive, creative, and characterless. In the implementation of the curriculum, as the operationalization of the curriculum concept, it is still written in nature which becomes actual in the form of learning, where learning in the classroom becomes a place to implement and test the curriculum to ensure the implementation of the curriculum in schools runs well.

The aforementioned description shows the need for an evaluation of French language curriculum implementation in high school to get information about the readiness, implementation, and results of the French language curriculum. Readiness includes the readiness of books, teachers, infrastructure, and the condition of lesson plans in each school. The implementation includes the process and evaluation of learning French at school, and the implementation results are the learning outcomes of students. The researchers conduct this research on the implementation of the French language curriculum because French is a cross-field study that is attracting students' interests. Moreover, in the French language curriculum implementation, teachers experience constraints in making French language learning plans that are easy for students to understand in terms of material, readiness, and implementation. Therefore, this study is focused on evaluating the implementation of the French language curriculum in senior high school.

The curriculum is a system usually more contained in written form (Hasan, 2009, p. 32). This dimension gains a lot of attention because its form can be seen and easily read and analyzed (Arifin, 2011, p. 9). Thus, the preparation of the curriculum must be in accordance with the components, rules, and structure in the curriculum. As a basic reference in the implementation of education, the curriculum plays an important and strategic role in the progress of a program, especially in the field of education (Kurniawan, Winarno, \& Dwiyogo, 2018). The components in the compiled curriculum must contain planning in the learning process and the development of students in the objectives, content, and teaching materials, which must be in accordance with educational objectives (Arifin, 2011, pp. 6-7; Dündar \& Merç, 2017, p. 137), so that, later, in the development and implementation of the curriculum in each subject, it will be following the rules and systems in the educational curriculum. It will be realized that all students will achieve academic success only if the curriculum is brought in line with the leadership skills and the education institution implements the right curriculum (Sorenson, Goldsmith, Méndez, \& Maxwell, 2011, p. 5), but there are still many data found in the field that plans exist in the curriculum is still not specific and too general, so the curriculum implementers themselves still cannot understand the curriculum well.

Evaluation and curriculum have characteristics and roles in every education and social research (Hasan, 2009, p. 32), so the two components do have quite dominant relationships. The broad curriculum evaluation is not only about activities in the classroom but also a comprehensive assessment process that involves all educational components such as students, teachers, models and methods of teaching, administration, and facilities (Ismail, 
2015, p. 15). The purpose of the curriculum itself is to introduce academic discipline to students so that they can use their knowledge with discipline and wisdom (Schiro, 2017, p. $25)$. The curriculum in education in Indonesia experiences significant changes and developments. This is intended to make the curriculum itself be able to improve learning implemented in schools. The focus on the curriculum is to ensure that the program achieves the mission and goals it has set. The curriculum in high school which was implemented in this decade is the 2013 curriculum.

Changes in the contents of the Education Unit Level Curriculum or Kurikulum Tingkat Satuan Pendidikan (KTSP) and 2013 Curriculum in French should be able to make students able to understand the basic learning of French, especially because it changes into cross-interest subjects. However, the reality that occurred in the three schools that have been observed, they actually experience difficulties because the material to be studied is more complex. The teacher feels it difficult in making learning material that is suitable for the ability of students in learning French. The new challenges in the 2013 curriculum become an important lesson that must be completed by the teacher so that students are able to understand French lessons well. In addition, the main element that must be prepared by a teacher before teaching is to prepare approaches, strategies, techniques, and learning procedures so that they can run the teaching effectively (Dewantara, 2017, p. 20). Based on observations that have been made, problems regarding planning, learning, and student assessment results in teaching French are found. Therefore, an evaluation of the 2013 curriculum in French subjects is needed to fit the objectives in the 2013 curriculum. After evaluating the curriculum, the steps that must be taken are knowing how to implement the improved curriculum, whether it has already been referred to as an improvement in learning and the quality of education, or it has not yet been carried out to the maximum.

Based on the background description of the problem that has been described, the evaluation carried out in this research is an evaluation by the Stake countenance model which includes planning, implementation, and results. This research focuses on preparing the learning implementation plan, learning implementation, and the results obtained by students so that later an accurate evaluation can be made in the implementation of learning French. The formulation of the problems found in this research is as follows: how the implementation of the curriculum of French Subjects in high schools in Sleman Regency is viewed from planning, implementation, and learning outcomes. The purpose of this research is to describe the implementation of French language learning in high schools in terms of the planning, implementation, and results components.

\section{Method}

The method of this research was curriculum evaluation. In curriculum evaluation, evaluation becomes a main part of the world of education considering the curriculum is always developing and changing according to the context in its era (Hasan, 2009, p. 41). Curriculum evaluation in this research was carried out on the implementation of the French subject curriculum in high school. The evaluation model used was the Stake Countenance model. This model emphasizes two main things, which are drawing and considering. These two main things are obtained through the evaluation stages, they are: (1) the planning stage (antecedent) which includes planning in learning by looking at the readiness of learning in the preparation of lesson plans; (2) the implementation/process (transaction) stage, which was the implementation of French learning in the preliminary, core, and closing activities; (3) the results and assessment phase, namely the measurement of the results of the French learning assessment which includes aspects of attitude, knowledge, and skills and see the suitability of techniques, instruments, and follow-up conducted by the teacher in the implementation of learning French.

Characteristics in countenance evaluation models are evaluating the interrelation (contingency) at each stage and congruence between planning, implementation, and results to reach the consideration stage. Consid- 
eration is given to standards/criteria. The planning, implementation, and learning outcomes in this research are based on the Regulation of the Minister of Education and Culture of the Republic of Indonesia No. 22 of 2016. In addition to the Regulation of the Minister of Education and Culture No. 103 of 2014, the results also refer to the Regulation of the Minister of Education and Culture No. 4 of 2018 and the Minimum Completeness Criteria or Kriteria Ketuntasan Minimal (KKM). Sources of data/research respondents were students in class $\mathrm{X}$ of senior high school. The sampling technique used was a random sampling technique. Random sampling technique is a method of random sampling from members of the population and is taken using a table/number generator (Sarjono \& Julianita, 2011, p. 23). The random sampling technique in this research was conducted by selecting two classes in each school. Data collection techniques in this research used the research of lesson plans, observations, questionnaires, and documentation. The questionnaire in this research is the main instrument used in data collection. Likert Scale is a scale used to measure the attitudes, opinions, and perceptions of a person or group of people towards an event or social situation where the variable to be measured is translated into an indicator variable then the indicator is used as a starting point for compiling question/statement items (Sarjono \& Julianita, 2011, p. 6). The questionnaire used was a Likert scale with a rating scale of 1-4. There are two types of respondents in the questionnaire namely teachers and students, three teachers, and 145 students from three schools. The data collection technique used in this research is in the form of Lesson Plan research.

The Lesson Plan research was used to find out the planning components that exist in implementing French learning in the three high schools in Sleman Regency where the research was conducted. The documentation used in this research is the value of students used in the results component. This research used content validity and construct validity. The content validity used Aiken validity and the construct validity used Exploratory Factor Analysis with the help of SPSS. In this re- search, the content validity was carried out by five experts (expert judgment), namely three lecturers who were experts in the field of language learning. The results obtained from 117 items from 71 indicators are that there is one statement that is failed because it does not have relevant relevance so that there are 116 items tested. In conducting trials and research conducted on three teachers, 145 students, and three Lesson Plan, 116 validated items were used.

The construct validity in this research was proven using factor analysis. Factor analysis is a statistical method that is commonly used in the development of measuring tools to analyze the relationship between variables (Azwar, 2018, p. 121). Thus, factor analysis answered the relationship and validity of the items in the instrument. The exploratory factor analysis (EFA) procedure helps develop tests in recognizing and identifying various factors that help construct by finding the largest score variance with the least number of factors expressed in the form of eigenvalue $>1$. Construct validity according to Nunnally and Fernandes (Retnawati, 2014, pp. 2-3) is validity which shows the extent to which the instrument reveals a certain theoretical ability or construct that is intended to measure. Construct validity is related to the provenience of the measurement result score. The construct validity can be proven by testing that the instrument construct does exist and empirically proven to confirm the existence of the construct of an instrument. The validity test model used was using $\mathrm{KMO}$ which is said to be valid if the KMO number is greater than 0.5 and the significance is the senior high school of more than $5 \%$. On the diagonal axis anti-image correlation, all must be greater than 0.5 if there are less than 0.5 then the item is removed (Priyatno, 2009). Factor analysis is used to test the correlation between variables. To test the correlation between variables, the Barlett's test of sphericity and the Kaiser-Meyer-Olkin (KMO) test were used. If the results are significant with a KMO value above 0.5 , then there is a significant correlation with several variables. The construct validity in this research was used on the student questionnaire with the result that five state- 
ments fell out of the 26 items that existed. The final results of the acquisition of KMO and Bartlett's test and the Rotated Component Matrix are as follows. KMO is used to determine whether all data that have been taken are sufficient to be factored measuring the adequacy of the sampling (sampling adequacy). This value compares the magnitude of the observed correlation coefficient with a partial correlation coefficient, a small KMO value indicates that the correlation between pairs of variables cannot be explained by other variables. If the sum of the squares of partial correlation coefficients among all pairs of variables is of small value compared to the sum of the squares of the correlation coefficient, it will produce a $\mathrm{KMO}$ value close to 1 . The KMO value is considered to be sufficient if more than 0.5. From those results, it can be said that the sampling that has been met can be used for further analysis.

Based on Table 1, the KMO from the SPSS calculation is 0.815 , so it is greater than 0.5 , and Bartlett's Test is 0.000 so it is said to be good. The conclusion obtained is that the data can be used for further testing. From the results of the calculation of the Rotated Component Matrix, it is known that there are six factors that affect the 21 items with details, namely component/factor 1, that is apperception and preparing a learning plan affecting items 1, 2, 3, 4; component 2, namely core activities affecting items $5,10,15,16,17,18$, 19 ; component 3 , namely mastering the material taught that influences point 14; component 4 , containing the use of media in learning influencing items 5, 6, 7; component 5, regarding asking how the understanding and involvement of students influence points 20, 21; and on factor/component 6 about ending learning influencing points 23, 24, 25, 26.

Instrument reliability in this study was estimated by looking at the Alpha coefficient. Reliability estimation is done by reliability ana- lysis using SPSS program computer ver.22.0 for Windows. To find out the alpha coefficient, the Alpha-Cronbach value for the reliability of all items in one variable was observed. The reliability test is said to be good if it is more than 0.7 (Mardapi, 2017, p. 25). The reliability test results in this study were 0.77 and 1 and more than 0.7. It shows that the student questionnaire reliability is good so that it can be used to test the implementation of the curriculum in the implementation of French language learning in high school.

The analysis technique used in this study is a descriptive statistical analysis technique using the SPSS program through a quantitative approach. It also uses a normal distribution with the following details (Azwar, 2018, p. 148): if the results are said to be not good, if the results obtained are said to be not good, if the results are said to be good, if the results obtained are said to be very good, if it is the average overall score, if it is the standard deviation of the overall score, and if it is the score achieved by students. In the planning category for the teacher questionnaire, if a score of $\mathrm{x}<12.25$ is obtained, the results are said to be not good; if the score is between 12.25-17.74, the results are said to be not good; if the score is between 17.75-22.75, the score is said to be good; and if the score is more than 22.75 , the results are stated to be very good. Furthermore, in the implementation category in the teacher questionnaire, if a score of $\mathrm{x}<41$ is obtained, the results are said to be not good; scores between 41-52.00 are said to be not good; scores between 52.0163.00 are said to be good; and if the score is more than 63.01, the results are stated to be very good. For the implementation category for the students' schedule, if a score of $\mathrm{x}<37$ is obtained, the results are said to be not good; if the score is between $37-52.75$, it is said to be not good; the scores between 52.76 - 68.25 are said to be good; and if the score is

Table 1. KMO and Bartlett's Test

\begin{tabular}{|c|c|c|}
\hline \multicolumn{3}{|c|}{ KMO and Bartlett's Test } \\
\hline \multicolumn{2}{|c|}{ Kaiser-Meyer-Olkin Measure of Sampling Adequacy } & .815 \\
\hline \multirow[t]{3}{*}{ Bartlett's Test of Sphericity } & Approx. Chi-Square & 1091.993 \\
\hline & df & 210 \\
\hline & Sig. & .000 \\
\hline
\end{tabular}


more than 68.25 , it is said to be very good. In the results category for the teacher questionnaire, if a score of $x<34$ is obtained, the results are said to be not good; a score between $34-42.5$ is said to be poor; a score between 42.6-51 is said to be good; and if the score is more than 51 , the results are stated to be very good.

\section{Findings and Discussion}

Planning in learning is done by using the Lesson Plan. The Lesson Plan is an important component that must be present and made by the teacher before carrying out learning, because it is a plan in describing a teacher in carrying out learning to start learning, giving material, using media, and using assessment instruments that are appropriate to the method and given to students.

In this research, there were three lesson plans analyzed and 37 items in the lesson plan review instrument using a score of 0.0. The calculations in the review of the Lesson Plan are used as the main instrument in planning (antecedent) with Formula (1). The results were analyzed with the planning table criteria (Arikunto, 2018, p. 35) presented in Table 2.

$$
\text { Score }=\frac{96}{108} \times 100=88,9
$$

Table 2. Lesson Plan Results

\begin{tabular}{cc}
\hline Percentage & Result \\
\hline $80-100 \%$ & \\
$66-79 \%$ & \\
$56-65 \%$ & $88.9 \%$ \\
$40-55 \%$ & \\
$<40 \%$ & \\
\hline
\end{tabular}

Table 2 is obtained from the evaluation standard criteria by Arikunto (2018). Descriptive percentages are used to facilitate the analysis of the evaluation of the French language curriculum in high schools based on established standards. The results are then interpreted and presented with numbers at the description stage, not until the generalization stage. Quantitative data analysis using descriptive techniques is used to process data from the questionnaire results obtained that are used to be able to evaluate concerning the techniques used.
From the results of the lesson plan analysis, it is found that it received a presentation score of $88.9 \%$. Then the score is compared with the planning criteria by knowing that the preparation of the Lesson Plan 100\% has good results when viewed from the criteria. It can be said that the Lesson Plan of the five schools has a very good suitability of $88.9 \%$. In this planning component, besides using the lesson plan, there is also a teacher questionnaire instrument consisting of seven statement items with the following categorization. The results obtained from the teacher questionnaire in the planning components of preparing lesson plans, designing learning, and evaluating French learning are equal to 25.7, so that it falls into the very good category.

In the component of implementation (transaction) in this research, 45 items of teacher questionnaire and 26 items of student questionnaire were used. The student questionnaire was filled in by 145 respondents, namely students consisting of five schools, namely Depok 1 High School, Kalasan 1 High School, and Angkasa Adisucipto High School, located in Sleman Yogyakarta. Based on the results of the research as a whole, the results of the implementation of French Language Learning in the three schools are included in either category. From the 26 statements of the student questionnaire in the implementation of learning, five statements fall after the Exploratory Factor Analysis (EFA) test using SPSS.

The results of student questionnaire calculations in the implementation of French learning in senior high school obtained an average value of 66.19 so that it is included in the good category. The next aspect is the presentation of student questionnaire results in the implementation component of French learning.

In addition to using student questionnaires, the implementation component also uses a teacher questionnaire instrument which amounts to 21 statements with scores ranging from 1-4, like the student questionnaire. From the calculation of the teacher's questionnaire, a value of 77 is obtained. The results are above 63 so it is included in the very good category. 
The results in this research were carried out using the Mid-Semester Assessment, teacher questionnaires, and interviews. The results of this research were obtained by looking at the behavior and assessment results obtained by the teacher with a total of 17 statement items. Based on calculations in the component results from the teacher questionnaire, a value of 65.7 is obtained, so it is included in the very good category.

Planning in evaluating the implementation of the curriculum has an important role so it is known how the preparation of lesson plans and teacher responses in implementing learning that will be done to students, in this case the cross-interest subjects in French. In the planning component, it is measured using the Lesson Plan research instrument and teacher's questionnaire. From the review of the Lesson Plan, it is found that the preparation of the Lesson Plan is known to be very good and the preparation reached $88.9 \%$. Whereas, in the teacher questionnaire, the planning component achieved $93.52 \%$ success, so the planning is included in the excellent category.

In the French Lesson Plan, all components meet good requirements in the preparation of the Lesson Plan in line with the syllabus and the Ministry of Education and Culture. Based on research that has been done, the planning component using the main instrument, namely the Lesson Plan review, is supported by a teacher questionnaire that gets very good result. Research that supporting the results of this planning component is found in research by Abrory and Kartowagiran (2014) that planning in preparing lesson plans has been included in the good category, even though the 2013 curriculum has just been applied. Other research that supports the planning component in this study is the study by Lukum (2015) which makes learning plans in the good category so that teachers are known to be able to compile lesson plans well. Another relevant research is conducted by Dewantara (2017) which shows that in planning Indonesian learning, it has been done well and shows the suitability of planning with the standard policy process that is being applied.
The main instrument used in this research is a questionnaire, namely the teacher's questionnaire and student questionnaire. The interview and observation were used as supporting instruments. In evaluating the curriculum, the implementation is a provider of information as an input in decision making (Hasan, 2009, p. 42), then the implementation must meet the criteria to achieve the results and objectives set. The implementation of the French language learning in the three high schools in Sleman Regency obtained good results.

Research supporting the results in this research is a study by Prasojo, Kande, and Mukminin (2018) which state that the implementation of learning is still not in accordance with the standard process because it is hampered by the process of motivating learning, learning media, and identification of students' abilities, even though the results in the questionnaire were already well. Thus, there needs to be a deeper review. Another research relevant to this study is a research by Kurniawan et al. (2018) that the implementation component is good but there are still some components that do not meet the qualifications of the process standard.

In the implementation of learning, one of the main keys to success is the qualification of an educator. Hence, educators who already have a lot of teaching experience still need self-development as lifelong learners and need to open themselves to various educational innovations that can support learning (Sumual \& Ali, 2017, p. 348). These studies indicate that many factors affect achievement in the implementation of learning so that all indicators must be reviewed and considered. The outcome component of this research was seen using the teacher questionnaire instrument and supporting instruments using interviews. From the results of teacher questionnaires, it is known that the preparation, reporting, remedial, and follow-up have been done well by the teacher by looking at the results of the grades obtained by students. In this case, the teacher is greatly helped by the assessment criteria that have been deter-mined from the specificity of the specified curriculum, namely the assessment of knowledge, attitude assess- 
ment, and skills assessment. Guidelines regarding assessments in learning the 2013 curriculum for high schools are contained in the Regulation of the Minister of Education and Culture No. 4 of 2018. Teacher activities to find out the results obtained by students are conducting assessments, planning follow-up activities in the form of remedial learning, enrichment programs, counseling services, and or assigning assignments groups and individuals in line with student learning outcomes.

Assessment of learning outcomes by educators is inseparable from the learning process. Therefore, the assessment of learning outcomes by educators shows the ability of teachers as professional teachers. The purpose of conducting an assessment according to the Regulation of the Minister of Education and Culture No. 4 of 2018 is to determine the level of mastery of competencies in attitudes, knowledge, and skills that have been and have not been mastered by a/group of students to be improved in remedial learning and enrichment programs and, establish mastery requirements learners' learning competencies in a certain period of time, i.e. daily, midterm, one semester, one year, and the period of research of the education unit, establish improvement or enrichment programs based on competency mastery levels for those identified as learners who are slow or fast in learning and achieving learning outcomes, improving the learning process at the next semester meeting.

In terms of the output component, the implementation of the assessment in learning French as a cross-interest lesson obtains good results by looking at the results of the midterm examination that has been conducted. The value gained by students varies because of the different characters they have. The average score obtained is 86.38 so that the learning carried out has been said to be good because all students have reached the Minimum Completion Criteria or Kriteria Ketuntasan Minimal (KKM), with a KKM in this subject that is 75 . However, there are still students who have not yet met the KKM in the middle semester assessment because of the different characteristics and abilities of diverse students, even though the teacher has given special treatment.
Research that supports the study in this component is a study by Lukum (2015) which shows that in the components of the students' assessment results reached $65 \%$ and is included in the category of sufficient, but still not met in achieving the KKM because there is no match between the planning and implementation of the standard process. The implementation of learning needs to be improved and adjusted again to the standard process. Moreover, this study still has shortcomings in the assessment because the results show that there are still students who have not reached the KKM even though the teacher has done variations in learning to ensure students can understand the subject matter well. Other research in line with this study is by Abrory and Kartowagiran (2014) that the quality of student outcomes has not yet reached maximum results because the value of attitudes, knowledge, and skills has not shown any conformity and achievement in accordance with the planned targets so it can be concluded that in the learning process that has not yet reached perfect results, it is necessary to develop each assessment carried out in learning as in this study. There are previous studies that are relevant to this research, namely research by Sumual and Ali (2017) that a learning outcome is very much determined by the experience and way of the teacher in teaching and giving direction to students. The results in this study are included in the good category because the teacher also has competence in teaching French well. This research has the uniqueness compared to other studies in terms of the planning with a French Language Learning Plan that is adapted, and the learning outcomes of students viewed from the results of the midterm examination that has been carried out to see and evaluate clearly the implementation of the French Language curriculum in high school. The results of the 2013 curriculum implementation are expected to be able to create interesting and meaningful learning for students, especially in French, as a cross-interest lesson that is encouraged by students. For this reason, in implementing the 2013 curriculum in French Language, schools need to continue to encourage the realization of national standards in schools. 


\section{Conclusion}

Based on the evaluation results of the implementation of the French subject curriculum that have been conducted at senior high school, the following conclusions are drawn: the planning (antecedent) of learning French contained in the Lesson Plan and the teacher questionnaire obtained a very good result; the implementation (transaction) of French learning in the teacher questionnaire and student questionnaire is in a good category. However, in reality, the learning undertaken is still not procedurally and structurally following the Lesson Plan so that the conclusions in the implementation of learning French subjects are included in the good category and need to be improved. The results (outcomes) in French Learning of the teacher's questionnaire are included in the very good category. Hence, overall, French learning is included in the good category and still needs improvement.

\section{References}

Abrory, M., \& Kartowagiran, B. (2014). Evaluasi implementasi Kurikulum 2013 pada pembelajaran matematika SMP negeri kelas VII di Kabupaten Sleman. Jurnal Evaluasi Pendidikan, 2(1), 50-59. Retrieved from http://journal.student. uny.ac.id/ojs/index.php/jep/article/vie $\mathrm{w} / 73$

Anh, V. T. K. (2018). Evaluation models in educational program: Strengths and weaknesses. VNU Journal of Foreign Studies, 34(2), 140-150. https://doi.org/ 10.25073/2525-2445/vnufs.4252

Arifin, Z. (2011). Konsep dan model pengembangan kurikulum. Bandung: Remaja Rosdakarya.

Arikunto, S. (2018). Evaluasi program pendidikan. Jakarta: Rineka Cipta.

Azwar, S. (2018). Reliabilitas dan validitas (4th ed.). Yogyakarta: Pustaka Pelajar.

Dewantara, I. P. M. (2017). Stake evaluation model (Countenance model) in learning process Bahasa Indonesia at Ganesha University of Educational. International Journal of Language and Literature, 1(1),
19-29. https://doi.org/10.23887/ijll. v1i1.9615

Dündar, E., \& Merç, A. (2017). A critical review of research on curriculum development and evaluation in ELT. European Journal of Foreign Language Teaching, 2(1), 136-168. https://doi. org/10.5281/zenodo.437574

Hamalik, O. (2008). Manajemen pengembangan kurikulum. Bandung: Remaja Rosdakarya.

Hasan, S. H. (2009). Evaluasi kurikulum. Bandung: Remaja Rosdakarya.

Ismail, F. (2015). The evaluation of curriculum implementation at Tarbiyah Faculty IAIN Raden Fatah Palembang. JISAE: Journal of Indonesian Student Assessment and Evaluation, 1(1), 12-27. https://doi.org/10.21009/JISAE.011.0 2

Johnson, R. B., \& Christensen, L. (2000). Educational research: Quantitative, qualitative, and mixed approaches. Thousand Oaks, CA: SAGE Publications.

Kurniawan, R., Winarno, M. E., \& Dwiyogo, W. D. (2018). Evaluasi pembelajaran Pendidikan Jasmani, Olahraga, dan Kesehatan pada siswa SMA menggunakan model Countenance. Jurnal Pendidikan: Teori, Penelitian, Dan Pengembangan, 3(10), 1253-1264. https: //doi.org/10.17977/jptpp.v3i10.11599

Lai, M., \& Kushner, S. (Eds.). (2013). A developmental and negotiated approach to school self-evaluation. https://doi.org/ 10.1108/S1474-7863(2013)14

Lukum, A. (2015). Evaluasi program pembelajaran IPA SMP menggunakan model Countenance Stake. Jurnal Penelitian Dan Evaluasi Pendidikan, 19(1), 25-37. https://doi.org/10.21831/pep. v19i1.4552

Majid, A., \& Rochman, C. (2014). Pendekatan ilmiah dalam implementasi kurikulum 2013 (E. Kuswandi, ed.). Bandung: Remaja Rosdakarya. 
Mardapi, D. (2017). Pengukuran, penilaian, dan evaluasi pendidikan (2nd ed.). Yogyakarta: Parama Publishing.

McCormick, R., \& James, M. (2019). Curriculum evaluation in schools. London: Taylor \& Francis.

Prasojo, L. D., Kande, F. A., \& Mukminin, A. (2018). Evaluasi pelaksanaan standar proses pendidikan pada SMP Negeri di Kabupaten Sleman. Jurnal Penelitian Dan Evaluasi Pendidikan, 22(1), 61-69. https: //doi.org/10.21831/pep.v22i1.19018

Priyatno, D. (2009). 5 Jam belajar olah data dengan SPSS 17 (J. Widiyatmoko, ed.). Yogyakarta: Mediakom.

Regulation of the Minister of Education and Culture No. 103 of 2014 on Lerning in Primary and Secondary Education., (2014).

Regulation of the Minister of Education and Culture No. 22 of 2016 on the Process Standard of Primary and Secondary Education. , (2016).

Regulation of the Minister of Education and Culture No. 4 of 2018 on the Assessment of Learning
Outcomes by the Educational Unit and the Government. , (2018).

Retnawati, H. (2014). Analisis kuantitatif instrumen penelitian. Yogyakarta: Parama Publishing.

Sarjono, H., \& Julianita, W. (2011). SPSS vs LISREL: Sebuah pengantar, aplikasi untuk riset. Jakarta: Salemba Empat.

Schiro, M. S. (2017). Teori kurikulum: Visi-visi yang saling bertentangan dan kekhawatiran tampa benti (B. Sarwiji, ed.; E. Sulistyowati, trans.). Jakarta: Indeks.

Sorenson, R. D., Goldsmith, L. M., Méndez, Z. Y., \& Maxwell, K. T. (2011). The principal's guide to curriculum leadership. Thousand Oaks, CA: Corwin Press.

Sumual, M. Z. I., \& Ali, M. (2017). Evaluation of primary school teachers' pedagogical competence in implementing curriculum. Journal of Education and Learning, 11(3), 343-350.

Tyler, R. W. (2013). Basic principles of curriculum and instruction. Chicago, IL: University of Chicago Press. 